\title{
ARTICLES \\ Filling the Gaps? Subsidiary Protection and Non-EU Harmonized Protection Status(es) in the Nordic Countries
}

\author{
Liv Feijen*
}

\begin{abstract}
The interpretation and use of subsidiary protection in Europe has received much attention in recent years. An area that has received considerably less attention is that of the residual forms of complementary protection that exist in national legislation but that have not been harmonized at a European level.

The key to understanding the contemporary use of complementary protection in the Nordic region lies in its origin and development to date. This article will therefore explain the conception of and contents of other complementary forms of protection and their use today compared to EU harmonized subsidiary protection. The article will analyse the existing legislation and practical examples of its application at first instance, on appeal, or by other precedent setting bodies.
\end{abstract}

\section{INTRODUCTION}

Prior to the adoption of the EU acquis on asylum, the Nordic countries were considered to be at the forefront of the use of complementary forms of protection. The Nordic countries had had domestic forms of complementary protection for decades, in addition to refugee status as stipulated by the 1951 Convention relating to the Status of Refugees (1951 Convention). The different types of status were called de facto status or humanitarian protection.

When the EU introduced subsidiary protection in Council Directive 2004/83/EC of 29 April 2004 on minimum standards for the qualification and status of third country nationals or stateless persons as refugees or as persons who otherwise need international protection and the content of the protection granted (Qualification Directive), the EU member states, Finland, and Sweden transposed the statuses as prescribed

* Doctoral candidate, International Law, Graduate Institute of International and Development Studies, Geneva. UN staff member. The opinions expressed in this article belong solely to the author and do not reflect the position of the UN. The author wishes to thank Professor Terje Einarsson, University of Bergen; Professor Emeritus Göran Melander, University of Lund; and Professor Jens Vedsted-Hansen, University of Aarhus, for sharing their comments and insights on earlier versions of this paper.

(C) The Author (2014). Published by Oxford University Press. All rights reserved. For Permissions please email: journals. permissions@oup.com 
while, at the same time, retaining the existing forms of complementary status. ${ }^{1}$ Norway, which is not an EU member state, chose to harmonize its legislation with the EU acquis, but also to keep its old forms of protection.

Denmark, although an EU member state, has a special arrangement, whereby it does not take part in any measures under Justice and Home Affairs, including asylum and migration. ${ }^{2}$ Consequently, Denmark is not party to any directive on asylum or migration and is not bound by the interpretations by the European Court of Justice in this field. Denmark has therefore not transposed the statuses of the Qualification Directive, but has developed its own interpretation of complementary protection based on the case-law of the European Court of Human Rights.

In recent years, there has been discussion as to (i) whether the Nordic countries should still have additional forms of protection; (ii) regarding the differing interpretations of subsidiary protection and other complementary forms of protection in the various countries; and (iii) whether it would be desirable for the EU to continue its harmonization by extending it to additional categories of persons in need of protection beyond the Qualification Directive.

\section{THE CONCEPT OF NON-EU HARMONIZED PROTECTION STATUS}

\subsection{What are the harmonized protection statuses within the EU?}

Pursuant to their obligations as EU member states under the area of Freedom, Justice, and Security, member states are required to harmonize their domestic legislation with the acquis in regard to refugee status and subsidiary protection in accordance with the EC Recast Qualification Directive, and temporary protection status in accordance with Council Directive 2001/55/EC of 20 July 2001 on minimum standards for giving temporary protection in the event of a mass influx of displaced persons and on measures promoting a balance of efforts between Member States in receiving such persons and bearing the consequences thereof.

The term 'harmonization' in this context means the approximation of domestic law by means of Community law standards. This is important to bear in mind because 'harmonization' implies that member states have a certain flexibility in introducing or retaining domestic regulations. The standards contained in the directives are minimum standards and member states are free to have higher, or more stringent, standards in accordance with article 288 of the Treaty on the Functioning of the European Union (TFEU) and special provisions in the directives, for instance, article 3 of the (Recast) Qualification Directive. According to Community case-law, if domestic standards are introduced, they shall provide more favourable conditions, they shall not 'undermine the coherence of Community action' and, finally, they shall be in conformity with the Treaty.

\footnotetext{
The Qualification Directive was replaced in 2011 by Directive 2011/95/EU of 13 December 2011 on the standards for the qualification of third-country nationals or stateless persons as beneficiaries of international protection, for a uniform status for refugees or for persons eligible for subsidiary protection, and for the content of the protection granted (the Recast Qualification Directive).

Protocol on the position of Denmark, adopted by the 1997 Amsterdam treaty OJ 1997, C340.
} 
One of the main objectives of the Qualification Directive was to codify the status of certain groups that had been identified as persons in need of international protection in domestic practice, but that, until then, had not been comprehensively regulated in international law. They were referred to as de facto refugees, in contradistinction to de jure refugees, that is, refugees as defined by the 1951 Convention. The groups that the drafters agreed to include in the new concept of subsidiary protection were so-called 'war refugees', fleeing indiscriminate violence and persons falling under the scope of article 3 of the 1950 European Convention for the Protection of Human Rights and Fundamental Freedoms (ECHR) and article 3 of the 1984 UN Convention against Torture and Other Cruel, Inhuman and Degrading Treatment or Punishment (CAT).

The legal basis for an obligation to grant status to 'war refugees' or people threatened by indiscriminate violence can be traced back to the travaux préparatoires of the 1951 Convention, where this is an area specifically foreseen for the application of the 1951 Convention, albeit with a nexus to the refugee grounds. ${ }^{3}$ The atrocities of war were considered to be captured within the definition of 'persecution. ${ }^{4}$ Prior to the adoption of the Qualification Directive, the Committee of Ministers of the Council of Europe recommended in several resolutions that subsidiary protection should be granted to persons fleeing their country of origin because of indiscriminate violence. ${ }^{5}$

UNHCR's Executive Committee recommended its member states that complementary protection outside the scope of the 1951 Convention should be granted when 'a need for international protection arises where such protection is lacking, either as a matter of law or as a matter of fact, with the result that basic human rights are seriously at risk. Such a situation typically comes about in relation to persecution, threats to life and personal security, armed conflict, serious public disorder or other man-made disasters. ${ }^{6}$

The recognition of the protection needs of persons displaced because of armed conflict has progressively become integrated into international law through the adoption of the 1969 OAU Convention Governing the Specific Aspects of Refugee Problems in Africa and the 1984 Cartagena Declaration on Refugees, and by the extension of UNHCR's competence ratione personae by the UN General Assembly and the Economic and Social Committee to cover situations of forced displacement resulting from conflict, indiscriminate violence, and public disorder. ${ }^{7}$ However, since the 1980 s,

T Einarsen, 'Drafting history of the 1951 Convention and the1967 Protocol' in A Zimmermann (ed), The 1951 Convention relating to the Status of Refugees and its 1967 Protocol: A Commentary (OUP 2011) 67.

This was also explained in UNHCR's Handbook on Procedures and Criteria for Determining Refugee Status of 1992, paras 164-66. cf, V Holzer, 'The 1951 Refugee Convention and the Protection of People Fleeing Armed Conflict and Other Situations of Violence' (UNHCR, Legal and Protection Policy Research Series, Sept 2012); S Juss, 'Problematizing the Protection of "War Refugees": A Rejoinder to Hugo Story and Jean-Francois Durieux' (2013) 32 RSQ22-124.

cf Council of Europe, Recommendation 18 (2001) of the Committee of Ministers to Member States on Subsidiary Protection, 27 Nov 2001.

UNHCR, 'Providing International Protection Including Through Complementary Forms of Protection': EC/55/SC/ CRP.16 (2 June 2005) para 2. See also UNHCR, 'Complementary Forms of Protection: Their Nature and Relationship to the International Refugee Protection Regime’: EC/50/SC/C (9 June 2000). See also, the comprehensive study on complementary protection, R Mandal, 'Protection Mechanisms Outside of the 1951 Convention ("Complementary Protection")' (UNHCR, Legal and Protection Policy Research Series, PPLA/2005/02, June 2005).

UNHCR, 'Statement on Subsidiary Protection Under the EC Qualification Directive for People Threatened by Indiscriminate Violence' ( Jan 2008) 1-2. 
it has been the group that has most frequently received complementary protection in the industrialized world. ${ }^{8}$ The protection accorded this category was primarily a form of humanitarian status for persons in a 'refugee-like situation', giving them protection from refoulement but not a right to admission on protection grounds per se. ${ }^{9}$

\subsection{Non-EU harmonized protection status}

The European Migration Network (EMN), which was established by the European Council to provide information on migration and asylum to support policy-making in the EU, conducted a study, in 2010, in twenty-three European countries to compare practices in regard to the use of non-EU harmonized protection status. ${ }^{10}$ EMN concluded that EU member states primarily use three categories of complementary protection, apart from the ones stipulated by the acquis.

The first is protection status(es) consistent with the Convention refugee definition and the EU acquis, for instance, national temporary protection statuses, exceptional residence permits on the basis of an international agreement, protection statuses on humanitarian grounds, and residence permits on humanitarian grounds for third-country nationals who can prove that there is a risk to their safety if they return to their country of origin to obtain a visa. The second category includes additional protection statuses, based on the principle of non-refoulement or on technical or practical constraints to return, for example, statuses on medical grounds, for family reasons, for unaccompanied children, stateless persons, and for tolerated stay/suspension of removal. The final category identified by EMN is other stays or permits to stay, for instance, for victims of trafficking, witnesses in criminal proceedings, victims of environmental disasters, and so forth. This article will only focus on persons in a 'refugee-like' situation.

\section{COMPLEMENTARY FORMS OF PROTECTION IN THE NORDIC COUNTRIES}

\subsection{Denmark}

\subsubsection{De facto status and B-status}

Denmark has not transposed the EU directives into its national legislation. It is however noteworthy that Denmark was one of the countries that provided inspiration for the contents of subsidiary protection when the Danish delegation, in 1997, proposed

J Cels, 'European Responses to De Facto Refugees' in G Loscher, and L Mohahan (eds), Refugees and International Relations (Clarendon Press 1990) 188, 200.

It is also worth mentioning that temporary protection has been used throughout history as a means of ensuring the protection against refoulement in exceptional situations of mass influx due to generalized violence or internal armed conflict. Within the EU, it is regulated in Council Directive 2001/55/EC of 20 July 2001 on Minimum Standards for Giving Temporary Protection in the Event of a Mass Influx of Displaced Persons and on Measures Promoting a Balance of Efforts Between Member States in Receiving Such Persons and Bearing the Consequences Thereof. In the international protection regime, temporary protection developed as a tool for burden-sharing in a situation of mass influx and not as a protection status. This fact notwithstanding, EU member states transposing the EC Temporary Protection Directive have sometimes treated it as a separate protection status in their national legislation and certain countries use it as a complementary form of protection, which has created some confusion as to its meaning.

10 European Migration Network, 'The Different National Practices Concerning Granting of Non-EU Harmonized Protection Status' (Dec 2010) 4-7. 
article 3 of the ECHR as an alternative legal basis for protection in the Qualification Directive. ${ }^{11}$ Denmark had used the concept of de facto refugees in its own administrative practice since the 1960s and it was formally included in the Aliens' Act in 1983. According to the old wording of section 7(2) of the Danish Aliens' Act prior to 2003, an alien who did not qualify for refugee status could be granted a residency permit if, because of similar grounds (lignende grunde) to those of the Convention, or other weighty grounds (tungtvejende grunde), that would result in a well-founded fear of persecution or equivalent harm, it could not be required that the applicant returned to his country of origin. This provision was interpreted as giving a real (de facto) right to a residency permit for persons who risked being subjected to concrete and individual persecution of a certain intensity. ${ }^{12}$

The concept of 'similar grounds' was interpreted as implying that the grounds were those of the Convention, but the claim did not reach the standard of proof required for refugee status, or, even though a risk of human rights violations could be established, it did not meet the persecution standard required by the Convention. ${ }^{13}$ 'Other serious grounds' was interpreted as meaning 'on grounds not derived from the Convention as it was interpreted in Danish practice.' This included draft evaders from countries at war, persons facing punishment because of unauthorized or prolonged stay outside their country of origin, 'republic refugees' from Eastern Europe risking persecution because they had sought asylum in the West, or persons at risk of persecution because of their sexual orientation or gender-related persecution. As pointed out by Vedsted-Hansen, in most countries, several of these categories are covered by an inclusive interpretation of the refugee ground, 'a particular social group. ${ }^{14} \mathrm{He}$ explains the rationale for the restrictive interpretation of the Convention grounds and the generous application of de facto status as borne out of the Danish legal tradition of pragmatism.

The fact that there was an internal armed conflict in the country of origin or generally difficult circumstances in terms of social conditions, lack of education opportunities or insufficient health services, was not considered sufficient to warrant protection under this provision. Despite this, the Refugee Appeal Board exceptionally decided to apply it to all Somali asylum seekers in $1992 .{ }^{15}$ The reason given was that it could not be established who was in control of the territory in Somalia and the general situation was so uncertain that it could not be required that the applicants returned. In this case, an individual determination of the protection needs was not considered to be required, but the determination was made with reference to the general situation in the country. The provision in section 7(2) was also considered applicable to categories other than those covered by the Convention, where Denmark had international obligations according to various treaties to refrain from returning a person.

\footnotetext{
11 Note from the Danish Delegation to Migration and Asylum Working Parties on 'Subsidiary Protection', 6764/97, ASIM 52, 17 Mar 1997.

12 Flygtningenaevnet, Formandskapet, 12 beretning, Copenhagen, 2004, 57-58. N Lassen, 'Comparative Legal Study on Subsidiary Protection' in D Bouteillet-Paquet (ed), Subsidiary Protection of Refugees in the European Union: Complementing the Refugee Convention (Bruylant 2002) 366.

13 J Vedsted-Hansen, 'The Legal Condition of Refugees in Denmark, Symposium on the Human Rights of Refugees' (1994) 7 JRS 253-54; Lassen, ibid, 370.

Vedsted-Hansen, ibid 254.

K Kjaer, 'The Abolition of the Danish de facto Concept' (2003) 15 IJRL 254-75, 265.
} 
In 2003, the Danish de facto concept was abolished, in accordance with Law 365 of 6 June 2002 on changes to the Aliens' Act, and replaced with protection status, or B-status (beskyttelsesstatus). The explanatory commentary on the Law indicates that the purpose of the changes was to restrict the number of persons obtaining protection and to limit its scope to the minimum required according to the international conventions ratified by Denmark. ${ }^{16}$ The current wording of section $7(2)$ stipulates that a person can be granted protection status if 'the alien upon return to his country of origin risks death penalty or being subjected to torture or inhuman or degrading treatment or punishment'.

\subsubsection{Scope of B-status}

Section 7(2) of the Danish Aliens' Act is primarily based on the prohibition of torture in article 3 of the ECHR and article 1 of Additional Protocol $6 .{ }^{17}$ Moreover, the Danish B-status is similar to the qualification of subsidiary protection in article 15(a) of the Qualification Directive, apart from the fact that there is no mention of execution, only of the death penalty. Furthermore, there are no references to the categories covered by 15(c) at all and, although the categories included in 15(b) are referred to, the assessment of the element of risk and the standard of proof differ from that of the Qualification Directive.

B-status is intended to be complementary to refugee status in that it is applicable to similar situations. The second instance body, the Refugee Appeals Board (Flygtningenaevnet), exemplifies its current practice in regard to what constitutes harm in the application of section $7(2) .{ }^{18}$ The first category is for cases of disproportionate punishment amounting to inhuman or degrading punishment, for instance, an Iranian Kurd who had been arrested and tortured for having smuggled weapons and who faced punishment for having failed his reporting duty. ${ }^{19}$ Another use of B-status is when there are threats of harm by non-state actors but no causal link to the Convention grounds, for example, Afghans fearing retaliation from the Taliban, and a Ugandan applicant whose injuries were proved to have resulted from torture allegedly from non-state actors. ${ }^{20}$ Both of these categories are well covered by the case-law of the European Court of Human Rights and they are clearly complementary to refugee status.

Some categories are however accorded B-status despite the fact that the claims could have been considered under the refugee definition, most notably, imputed political opinion. In several cases that received B-status imputed political opinion could arguably have been used as grounds for refugee status instead, for example, an Afghan man who was suspected of having spied for the Taliban; an Iranian applicant who had refused to co-operate with national intelligence services; a Chechen who feared persecution from the authorities because he had assisted a rebel; and a Somali applicant who

\footnotetext{
16 Ministry for Refugees, Immigration and Integration, Hvidbog vedrorende lov nr 365 af 6 juni 2002 om aendring af udlaendingeloven og aegteskabsloven med flere love (Jan 2003). For an exhaustive account of the legislative process, see K Kjaer, ibid, 254-55.

Additional Protocol 13 did not enter into force until the following year.

Eg, Flygtningenaevnet, Formandskabet, 19. beretning 2010, Copenhagen 2011; Flygtningenaevnet, Formandskabet, 20. beretning 2011, Copenhagen 2012.

Iran/2010/13.

Afg//2011/4, Uganda/2011/1,
} 
feared his life was in danger from Islamic groups because he had provided transport for Government members in his minibus. ${ }^{21}$

According to contemporary interpretations of political opinion in the refugee definition, it is not required that a person in fact hold any political opinion, but it is sufficient that he is perceived by the persecutor as holding such an opinion in order to meet the threshold risk of persecution. It is the perspective of the persecutor that should be determinative in this respect. ${ }^{22}$ This principle is also confirmed in article 10(2) of the (Recast) Qualification Directive.

Another type of case that receives B-status instead of Convention refugee status is when applicants have a relative who has been persecuted for Convention, or non-Convention, reasons. In one illustrative example, a Sri Lankan woman had been interrogated and raped by the military because of her husband's activities. ${ }^{23}$ In cases where the persecution of a relative have a causal link to Convention reasons, refugee status could also have been granted to the applicant on imputed political or religious reasons. The evidence value of past persecution of relatives is that it can substantiate the wellfoundedness of the applicant's claim for refugee status. ${ }^{24}$

B-status was considered for persons claiming to be draft evaders and deserters in a number of cases. In these cases, the Refugee Appeals Board made an assessment of the proportionality of the punishment for having deserted, with a rather high threshold: 'the fact that the applicant risk a prison sentence because of his desertion, does not give grounds to grant asylum, but in the case of draft evaders, 'the fact that the applicant risk punishment because of draft evasion is sufficient to grant asylum.25 One applicant risking the death sentence for draft evasion was granted B status in 2010. ${ }^{26}$

The Refugee Appeals Board's practice here is in line with the explicit reference to protection from the death penalty in article 7(2). UNHCR's Handbook concurs that disproportionate punishment can be grounds for refugee status, while disproportionate punishment without nexus to the grounds may fall under inhuman or degrading punishment. ${ }^{27}$ By using B-status in cases of inhuman and degrading treatment cases, Denmark expands the scope of protection beyond that of refugee status, albeit within the realms of the protection of article 3 ECHR.

The Refugee Appeals Board has been very clear that the assessment of claims based on generalized violence lies outside its scope of work: 'The competence of the Board is ... limited to assessing questions relevant to asylum, that is, individual risk of persecution or harm, and it is therefore outside the competence of the Board to assess whether, an alien who does not fulfil the criteria in section 7 of the Aliens' Act, can be accorded a residency permit for other and more humanitarian reasons, for instance, because of temporary, generalized violence where the applicant does not fulfil the criteria of Article 7:28 The Refugee Appeals Board continues that 'an undoubtedly difficult - but

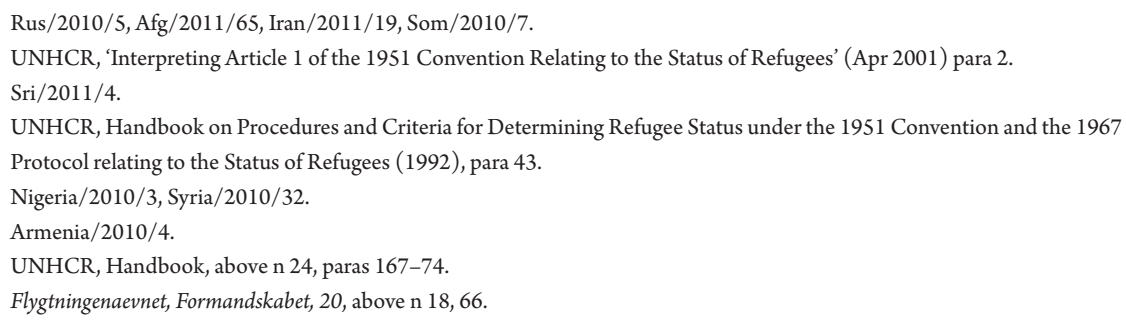


general - security situation in a country cannot by itself constitute grounds for asylum according to Article 7 of the Aliens' Act'. ${ }^{29}$

\subsubsection{Criteria for the risk assessment}

The Refugee Appeals Board explained the applicability of section 7 as: 'It is a condition for residency permit according to section 7 that, following an individual and concrete assessment, an alien is considered at risk of persecution or other harm (overgreb) that is the basis for asylum. ${ }^{30}$ Initially, a common criterion for risk assessment was established for both Convention and de facto status, namely, fear of concrete, individual, persecution of a certain intensity or a risk of (such persecution). It has been interpreted in practice as there having to be specifically qualifying circumstances directed against one particular individual, and the risk of harm has to be sufficiently concrete. ${ }^{31}$ It seems as if this is often interpreted as evidence of past persecution.

It should be noted that, in international refugee law, past persecution is not a prerequisite for recognition of future persecution, but it can be part of the facts that are assessed to determine future risk and used in the part of the assessment pertaining to the objective element. UNHCR's Handbook stipulates that 'it may be assumed that a person has a well-founded fear of persecution if he has already been the victim of persecution for one of the reasons enumerated in the 1951 Convention.' ${ }^{32}$ Past persecution therefore indicates a presumption that there will be continued persecution in the future. Article 4(4) of the (Recast) Qualification Directive goes further in providing that past persecution, serious harm or direct threats shall be considered as a serious indication of the applicant's well-founded fear of persecution or real risk of suffering serious harm, unless there are good reasons to consider that such persecution or serious harm will not be repeated. This is considered to lessen the requirement for the applicant to substantiate his or her claim of future risk and to instead shift the burden of proof to the authority to dispel the claim of future harm.

Based on an analysis of its practice, it seems that the Refugees Appeal Board applies a mixture of standards of proof in its assessment of B-status. In some cases, it utilizes a 'real risk', in the same sense as the ECHR in cases of inhuman or degrading treatment, but sometimes both refugee status and the risk of inhuman or degrading treatment are assessed in terms of 'concrete and individual' risk. The distinction between the two is somewhat unclear. According to Vedsted-Hansen:

the use of the criteria 'concrete and individual' and the later versions of 'concrete special risk' and 'concrete, real risk' ... has not only created doubt as to the adherence to convention of an essential element in Danish asylum practice. The criteria and their use have at the same time contributed to a state of law, which seems to have created a considerable crisis of legitimacy for the Danish asylum system, also by European standards. ${ }^{33}$

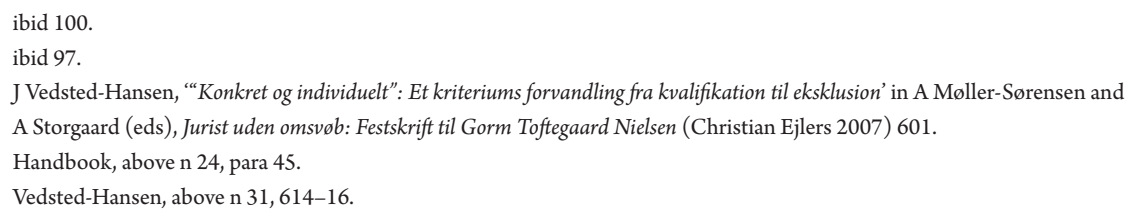




\subsubsection{Caveats}

There are two apparent deficits in the current application of B-status. One pertains to the fact that article 15(c) of the (Recast) Qualification Directive is not considered to be covered by the provision, which means that one important category of persons in need of protection completely falls outside the Danish protection regime, namely persons fleeing armed conflict. Vedsted-Hansen has proposed that the initial interpretations of the Refugee Appeals Board on the non-applicability of the provision to 'difficult circumstances' referred to when there is 'a situation similar to an armed conflict' and not when there actually is an internal armed conflict. He claims that subsequent practice expanded this interpretation to also exclude 'real' internal armed conflicts. ${ }^{34}$ In his opinion, persecution and harm that happen to occur during a situation of armed conflict should still warrant asylum.

It is possible to use the torture provision to encompass persons fleeing armed conflict, in line with recent practice by the European Court of Human Rights. In older caselaw, such as NAv the UK and FH v Sweden, the Court had stated that

it had never excluded the possibility that a general situation of violence in a country of destination will be of sufficient level of intensity as to entail that any removal to it would necessarily breach Article 3 of the Convention. Nevertheless, the Court would adopt such an approach only in the most extreme cases of general violence, where there was a real risk of ill-treatment simply by virtue of an individual being exposed to such violence on return. ${ }^{35}$

However, in 2011, the European Court of Human Rights pronounced in a case regarding two Somali applicants that return from the UK to Mogadishu would constitute a violation of article 3 of the ECHR because, 'the generalized violence in Mogadishu has reached a level where everyone may be at a real risk of harm in accordance with the Convention.' ${ }^{36}$ The Danish Appeal Board noted the decision by the Court and pronounced that, 'the Board has not at any time excluded the possibility that the general security situation in a country may assume such a serious and extreme character that the applicant fulfils the criteria for residency permit solely on this ground' and decided to suspend the cases until the judgment was final. ${ }^{37}$ However, practice from 2012-13 shows that claims from Somali applicants based on the general situation were rejected..$^{38}$ In 2013, the Danish Appeal Board acknowledged the deteriorating situation in Syria and the fact that persons originating from areas in Syria where there is armed conflict or attacks against civilians would be subjected to a real risk in accordance with article 3 .

ibid 603.

HLR $v$ France 11/1996/630/813 (Council of Europe: ECtHR, 22 Apr 1997) para 40; NA $v$ The United Kingdom App No 25904/07 (Council of Europe: ECtHR, 17 July 2008) para 115; FH v Sweden App no 32621/06 (Council of Europe: ECtHR, 20 Jan 2009) 90.

36 Sufi and Elmi v the United Kingdom App nos 8319/07 and 11449/07 (ECtHR 28 June 2011).

Flygtningenaevnet, Formandskabet, 20, above n 18, 49.

$<$ http://www.flygtningenaevnet.dk/Templates/PraksisSoegeside.aspx?NRMODE=Published\&NRNODEGUID=\%7b70 F54DDC-B66D-408B-AC3B-C96FD9767C36\%7d\&NRORIGINALURL=\%2fdadk\%2fPraksis\&NRCACHEHINT=N oModifyGuest>. 
It emphasized however that not all areas of the country were affected by the conflict and that an individual assessment is still required. ${ }^{39}$

However, it should also be noted that subsequent case-law from the European Court of Human Rights relaxes the burden of proof and kind of proof required for a 'real risk' of ill-treatment. In, for example, MSS v Belgium and Greece, the Court clearly pronounced that, "The fact that a large number of asylum seekers in Greece find themselves in the same situation as the applicant does not make the risk concerned any less individual where it is sufficiently real and probable. ${ }^{40}$ Moreover, in Hirsi v Italy, the Court made a prima facie assessment of the situation in Somalia and Eritrea based on the country of origin information without finding it necessary to assess an individualized real risk. ${ }^{41}$

Secondly, categories that would have been covered by a broad and inclusive interpretation of Convention refugee status were dropped when de facto status was abolished never to be picked up again. The concept of 'a particular social group' is, for instance, de lege lata by virtue of being explicitly included in the article of the Convention containing the refugee definition, against which it is not possible to have reservations. In regard to the interpretation of the concepts of the Convention, for example, imputed political opinion and gender-related persecution, the Convention is considered to be a 'living instrument', which, as explained by Goodwin-Gill, 'should be interpreted in light of present-day conditions and in accordance with developments in international law. ${ }^{42}$

\subsection{Finland}

\subsubsection{Humanitarian protection}

Chapter VI of the Finnish Aliens' Act (301/2004) contains the criteria for granting international protection. Section 31 of the 1991 Finnish Aliens' Act (378/1991) already contained a provision for protection for persons who would be threatened by capital punishment, torture, or other inhuman or degrading treatment, or because of armed conflict or environmental catastrophe upon return. A similar provision could be found in section 9(4) of the Finnish Constitution, also linking the principle of nonrefoulement with the danger of the death sentence, torture, or other treatment violating human dignity in case of return.

In 1999, the Aliens' Act was amended to provide residence permits to persons in need of protection or if it would be 'obviously unreasonable' to deny a residence permit. This latter category referred to capital punishment, torture or inhumane treatment, armed conflict, and environmental catastrophe. Such an assessment was not based on the need for international protection, but the personal circumstances of the applicant and had therefore a wider scope ratione personae. ${ }^{43}$

In 2003, the Act was again amended to clarify, in section 88, the 'need of protection' for aliens who 'are in their home country or country of permanent residence under the

<http://www.flygtningenaevnet.dk/da-dk/Nyheder/Nyhedsarkiv/2013/Flygtningenævnet+ændrer+praksis+som+følge + af + den+forværrede+situation $+\mathrm{i}+$ Syrien.htm $>$.

$40 \quad$ MSS v Belgium and Greece App no 30696/09 (ECtHR, 21 Jan 2011) para 359. Similarily, Hirsi Jamaa and Others $v$ Italy App no 27765/09 (ECtHR, 23 Feb 2012) para 136.

$41 \quad$ Hirsi Jamaa and Others $v$ Italy App no 27765/09 (ECtHR, 23 Feb 2012).

42 GS Goodwin-Gill, 'The Search for One True Meaning' in GS Goodwin-Gill and H Lambert (eds), The Limits of Transnational Law. Refugee Law, Policy Harmonization and Judicial Dialogue in the European Union (CUP 2010) 207.

43 E Nykänen, 'Comparative Legal Study on Subsidiary Protection - Finland' in Bouteillet-Paquet (ed), above n $12,404$. 
threat of the death penalty, torture or other inhuman treatment or treatment violating human dignity, or if they cannot return there because of an armed conflict or environmental disaster'.

In order to ensure transposition of the Qualification Directive and harmonize the protection grounds with other EU member states, the existing law and practice were assessed in 2007 and proposals were made for changes to the Aliens' Act, which were enacted in 2009. The category of persons in 'need of protection' was removed and replaced with the narrower concept of 'subsidiary protection'. The text of section 88 was amended to correspond to article 2(e) and article 15(a)-(c) of the Qualification Directive, save the phrase 'violating human dignity', which is derived from the Finnish Constitution and was considered to equate to the notion of 'degrading treatment' in the Directive. ${ }^{44}$

According to section 88(1)(3) of the Act, subsidiary protection will be granted to a person for whom substantial grounds have been shown for believing that the person, if returned to his or her country of origin or country of former habitual residence, would face a real risk of being subjected to serious harm, and he or she is unable, or owing to such risk, unwilling to avail him or herself of the protection of that country. Serious harm is found to mean the death penalty or execution, torture or other inhuman or degrading treatment or punishment, or serious and individual threat as a result of indiscriminate violence in situations of internal or international conflict.

However, with a reference to article 3 of the Qualification Directive allowing for more favourable provisions, a third protection ground, so-called 'humanitarian protection', was introduced. Humanitarian protection was proposed to contain the forms of protection that previously had been covered by persons in 'need of protection' but that could not be incorporated in 'subsidiary protection'. According to section $88 \mathrm{a}(1)$, 'humanitarian protection' can be granted to a person who cannot return to his or her country of origin or country of former habitual residence 'as a result of an environmental catastrophe or a bad security situation which may be due to an international or internal armed conflict or a poor human rights situation. ${ }^{45}$ Two categories have thereby been moved from the provision on subsidiary protection: victims of an environmental disaster and persons fleeing an armed conflict of lesser intensity than the one encompassed by subsidiary protection. The provision is tertiary in the sense that the applicant shall first be assessed for asylum and subsidiary protection and only if neither of theses statuses is applicable will humanitarian protection be considered.

Following an increase in the number of asylum applicants during 2007-8, the Government announced a set of thirteen restrictive measures on 3 September 2008, which were proposed 'to reduce the number of arrivals of persons not in need of international protection'. One of the measures related to the application of humanitarian protection, where the Government proposed that each case should be examined individually, and not undergo a general group assessment based on the particular geographical area.

44 Finnish Government Bill 166/2007 rd, for an act amending the Aliens' Act, Regeringens proposition till Riksdagen med förslag till lagar om ändring av utlänningslagen och av vissa lagar som har samband med den (2007) 29.

45 Law 323/2009. 
As a consequence, the Immigration Regulation was amended in 2009 to stipulate that the individual situation of each applicant should be assessed when applying section 38 of the Act. The decisive factors are not the applicant's nationality or the geographical region from which he/she originates, but the individual applicant's possibilities of returning to his/her country of origin. The Ministry may instruct the Directorate of Immigration to make exemptions in certain cases, see section 76 , paragraph 3 , of the Act.

\subsubsection{Scope of humanitarian protection}

According to the Administrative Committee of the Finnish Parliament, which commented on the proposal to change the Aliens' Act, section 88a would be applicable to persons who cannot return because of indiscriminate violence, which is not individualized. ${ }^{46}$ According to the Committee, the asylum authorities should first assess the protection needs in accordance with sections 87 and 88 and thereafter assess what consequences the general situation in the country of origin may have on the applicant in case of return in accordance with section $88 \mathrm{a}$. The second assessment is therefore not of eligibility, but of returnability.

Humanitarian protection can be granted if the situation in the country, objectively speaking, could result in real and serious danger because of the armed conflict for an individual in case of return. There should be a causal link between the armed conflict and the poor security situation. According to Government Bill 166/2007, the main difference between the two provisions on armed conflict in section 88 and section $88 \mathrm{a}$ is that, in the case of the latter, an assessment is made on the effects of the armed conflict on the civilian population as a whole. The Administrative Committee gives, as an example, the person residing in a place threatened by generalized violence without any internal flight possibilities within the country. ${ }^{47}$ If the battles take place in another part of the country, where the applicant is not residing, it is not considered as 'real and serious danger'.

According to the Administrative Committee, the definition of armed conflict includes armed conflicts regulated by the 1949 Geneva Conventions and its Additional Protocols, but also other types of armed violence and armed disturbances. The assessment should take into account the nature of the violence, its geographical location, its intensity, and to what extent there are violations of human rights and humanitarian law. The Committee also concluded that the assessment should consider the authorities' ability to monitor territories within its control and to guarantee its citizens' safety, and to what extent the judicial system can ensure the fundamental rights of citizens.

The Committee proposed however that the provision should not only be applicable to situations of armed conflict, but also to cases of massive human rights violations that have a detrimental impact on the security situation. However, it emphasized that, in order for this part of the provision to be applicable, it is not sufficient only to have documented violations of human rights in a particular country, there should additionally be a link to a grave security situation. The Committee added that this confirmed existing practice.

46 Report of the Administrative Committee on the Government Proposal for an act amending the Aliens' Act, Förvaltningsutskottets betänkande 26/2008 rd, Regeringens proposition med förslag till lagar om ändring av utlänningslagen och av vissa lagar som har samband med den (2008), HaVM 26/2008, 6. 
The provision on environmental catastrophe was intended to be used in situations where a man-made disaster has occurred in the country of origin or country of residence, leading to an inhabitable or dangerous environment. ${ }^{48}$ When the Aliens' Act was revised in 2003, it was considered whether to remove the provision on environmental disasters as a ground for protection. The reason for this proposal was partly because it was considered that the first option, when there is a natural disaster, is to seek protection in one's own country, not necessarily crossing international borders, and, secondly, because the international community normally assists in such situations in order to prevent an outflux. There would therefore not be the need for a specific ground for persons reaching Finland.

It was also put forward that it would be more appropriate to grant temporary protection in a situation of a natural disaster, since the need for protection should be of a temporary duration. However, it was eventually decided to retain the provision, with the clarification that it was intended to be used in situations where a man-made disaster has occurred in the country of origin or country of residence, which has led to an inhabitable or dangerous environment. ${ }^{49}$ The provision on environmental catastrophe has as yet not been applied in practice.

\subsubsection{Criteria for risk assessment}

In a study of the application of subsidiary protection and humanitarian protection in 170 sample decisions taken by the Migration Board in 2010, the practice concerning the general assessment of the country of origin information and the intensity of the risks was found to be assessed consistently, while the use of criteria for the individual risk assessment was less consistent. ${ }^{50}$ Moreover, the study concluded that, the factors that were taken into consideration in order to assess the general situation included the intensity of violence, geographic location, duration and forms of violence, the identity of the victims, type of weaponry used, identity of the parties to the conflict, degree of control over the territory by the Government, the overall humanitarian situation and the number of killed and displaced civilians. In general, these are the criteria that have been identified as the predominant ones in the European context. ${ }^{51}$ However, there were deficits in the application on individual cases.

\subsubsection{Caveats}

When the legislation was changed and the number of statuses increased, it was with the explicit intention that international protection should be granted more frequently. ${ }^{52}$ In the travaux préparatoires to the Act, both the Government and the Administrative Committee emphasized that the distinction between subsidiary protection and humanitarian protection in a situation of armed conflict is that in the former there is a

so E Nykänen, 'On the Lines of Demarcation and Their Significance. The Categories of Complementary Protection under the Finnish Aliens' Act', paper presented at the Nordic Asylum Seminar, Copenhagen, May 2011.

51 UNHCR, “Safe at Last?" Law and Practice in Selected EU Member States with Respect to Asylum-Seekers Fleeing Indiscriminate Violence' (July 2011) 42.

52 Above n 44, 50. 
requirement of serious and individual threat as a result of indiscriminate violence, while for humanitarian protection there is no requirement of individualization of the risk.

The interpretation of subsidiary protection as prescribed by the Qualification Directive in Finland, as in many other European countries at this time, was based on discussions in the European Commission's Contact Group. However, the interpretation of article 15(c) of the Qualification Directive by the European Court of Justice in the Elgafaji judgment put matters in a different perspective. ${ }^{53}$ According to the European Court of Justice 'individual' in the sense of the provision should be interpreted to cover harm to:

civilians irrespective of their identity, where the degree of indiscriminate violence characterizing armed conflict taking place ... reaches such a high level that substantial grounds are shown for believing that a civilian returned to the relevant country or, as the case may be, to the relevant region, would solely on account of his presence on the territory of that country or region, face a real risk of being subject o the serious threat referred to in Article 15(c) of the Directive. ${ }^{54}$

According to the Court, though, the threshold is so high that it is only reached under very exceptional circumstances. ${ }^{55}$ Moreover, the Court explains that the individualization of risk should be assessed according to a sliding scale in that 'the more the applicant is able to show that he is specifically affected by reason of factors particular to his personal circumstances, the lower the level of indiscriminate violence required for him to be eligible for subsidiary protection. ${ }^{56}$

Nykänen found in her study some uncertainty in practice, both in regard to the interpretation of subsidiary protection in line with article 15(c), as interpreted in Elgafaji, and in distinguishing between subsidiary protection and humanitarian protection. The question of what effect Elgafaji will have on the interpretation of subsidiary protection in Finland and the distinction between subsidiary protection and humanitarian protection was however partially covered by a precedent-setting ruling by the Finnish Supreme Administrative Court in 2010. ${ }^{57}$

The Supreme Administrative Court concluded that when examining the need for subsidiary protection both collective and individual facts must be taken into consideration, that it, an assessment should be made of both the general situation and the individual circumstances for the applicant. In the case at hand, that of a Sunni Muslim man from Baghdad, it was established that the applicant had not suffered personally from the effects of indiscriminate violence. However, the Court took into account the experiences of the applicant's acquaintances, as well as the general security situation in Baghdad presented in the country of origin information, in particular in regard to the nature of the violence and the long duration of the conflict, and concluded that he should be granted subsidiary protection. Since subsidiary protection was granted,

53 Elgafaji v Statssecretaris van Justitie C-465/07 (17 Feb 2009). Also, cf J McAdam, Complementary Protection in International Refugee Law (OUP 2007) 70-78.

ibid para 35.

ibid paras 37-38.

ibid para 39.

Supreme Administrative Court, KHO 2010:84, 30 Dec 2010. 
there was no need for the Court to assess the possible application of the tertiary status, humanitarian protection.

By removing the element of personalized threat when applying subsidiary protection, it puts into question the need for also having the status of humanitarian protection in situations of armed conflict. Humanitarian protection can however still be foreseen to have a clear added value is the second part of the definition, that is, 'a bad security situation, which may be due to ... a poor human rights situation'.

\subsection{Norway}

\subsubsection{Humanitarian protection}

A complementary form of protection, humanitarian protection, was introduced in section 15 of the Norwegian Aliens' Act of 1988, which was a provision on prohibition of refoulement, not a provision on eligibility. Section 15, second sentence, stipulated that: 'Corresponding protection shall apply to foreign nationals who for reasons similar to those given in the definition of a refugee are in considerable danger of losing their lives or of being made to suffer inhuman treatment.' 'Refugee-like' was explained in the travaux préparatoires to refer to a situation where the lack of rule of law or disregard for human rights led to a risk of harm. ${ }^{58}$ This additional ground was, according to the travaux préparatoires, inspired by the fact that articles 3 and 8 of the ECHR have a broader applicability than the Convention. ${ }^{59}$

According to the Government Bill proposing the Act, a new group of persons would be created through this addition, who, even though they would not qualify for asylum, would be protected from return. However, it was not considered justified to create a separate status for them, although they would benefit from 'asylum. ${ }^{60}$ The Committee on the Aliens' Act specifically emphasized that they did not want to call them de facto refugees or B-refugees, since it was found to be too narrow a concept. ${ }^{61}$

At the beginning of the 1990s, humanitarian protection became the ground predominantly utilized in the determination of claims, which resulted in a positive decision. ${ }^{62}$ According to Einarsen, the reason was that 'the Norwegian authorities prefer(ed) the increased legal flexibility and favourable public relations which flows from a system where Norway seems to protect many more than obliged to under the Immigration Act and international treaties. ${ }^{63}$ Einarsen however cautioned against the element of discretion as the administrative power to grant protection on humanitarian grounds may not always be exercised when someone in need of protection is not recognized as a Convention refugee. ${ }^{64}$

At the time there was no requirement of individual targeting in order to qualify for humanitarian protection, but a direct risk of serious danger had to be established. According to the travaux préparatoires, the threshold, both for the type of danger and

$58 \quad$ Proposisjonen Ot Prp Nr 46 (1986-87) om utlendingsloven 103.

59 T Einarsen, 'The Legal Condition of Refugees in Norway: National Implementation of Refugee Rights and the 1951 Geneva Convention' (University of Bergen Law Faculty publications, no 45, 1994) 45.

60 Above n 58, 96-97.

61 NOU 1983:47.

62 Einarsen, above n 59, 20.

63 ibid 20.

64 ibid 21. 
the likelihood that it would occur, is higher than for refugee status. The applicant should be at immediate risk of being killed or have been subjected to inhuman treatment. ${ }^{65}$ In cases of clear discrimination, the requirement of direct threat could be lessened, for example, in the case of women who suffered discrimination. ${ }^{66}$ Another category, intended to be captured by this ground, was persons who would have qualified for Convention status, but who were not considered eligible according to Norwegian practice because the actors of persecution were non-state agents. ${ }^{67}$ Finally, the ground was applicable to persons who had fled from a country with armed conflict, or violence between groups. It was recognized that persons who had been displaced because of such situations often lack individual grounds, but may still have valid protection needs.

In order to harmonize its legislation with the EU acquis, the Norwegian Aliens' Act was replaced by a new piece of legislation, Act of 15 May 2008 on the entry of foreign nationals into the kingdom of Norway and their stay in the realm, which entered into force in 2010. According to the new section 28(b), persons protected under conventions other than the 1951 Convention would be encompassed by the term refugee: an alien will be recognized as a refugee who, 'without falling within the scope of (a) nevertheless faces a real risk of being subjected to a death penalty, torture or other inhuman or degrading treatment or punishment upon return to his or her country of origin'.

\subsubsection{Scope of 'Asylum'}

Section 28 (b) is by and large used in the same manner as article 3 of the ECHR as interpreted by the European Court on Human Rights, in particular in regard to the interpretation of 'torture', 'inhuman and degrading treatment' and so forth. However, it has been envisaged that violations of rights contained in other international instruments, such as articles 2-3 of the ECHR, articles 6-7 of the International Covenant on Civil and Political Rights and articles 37a and 38(2)-(4) of the Convention on the Rights of the Child, could also be covered by this provision. ${ }^{68}$ Einarsen interprets this provision to also offer protection from international crimes, such as genocide, crimes against humanity, and war crimes. ${ }^{69}$

The category in section $28(\mathrm{~b})$ is distinguished from the refugee definition is section 28 (a) in that the reason for the feared harm is without consequence. Both provisions are now considered to be applicable to non-state actors, which was an important function of the old humanitarian protection.

\subsubsection{Criteria for risk assessment}

There is no requirement for a nexus between the harm and the reason of the feared harm, which eases the burden of proof on the applicant. ${ }^{70}$ The notion of 'real danger' is not defined in the law. However, according to the travaux préparatoires, it refers to a purely objective assessment, which has a higher threshold than 'well-founded fear.' ${ }^{71}$

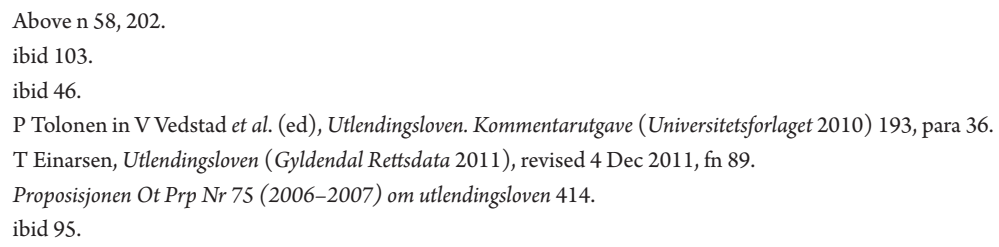


The Government Bill continues by stipulating that, 'If there is a risk of being killed or being subjected to torture, it would mean that there will be lesser obligation to make the danger probable than when it is a question of less serious effects'.

\subsubsection{Caveats}

According to the new status, the flexibility that was inherent in humanitarian protection has been removed. The most obvious caveat is that there is now no provision explicitly covering persons displaced because of indiscriminate violence. However, according to the Government Bill proposing the adoption of the provision, 'war refugees' was one category that was envisaged to be covered by subsection (b). ${ }^{72}$ The Committee conducting an inquiry in preparation of the law explicitly stated that:

Both EU's Qualification Directive and, among others, the Swedish and the Finnish Aliens' Act have a particular reference to situations with armed conflict etc. The Committee assumes that such instances will be covered by Article 3 of the European Convention on Human Rights i.e. the protection against torture or inhuman or degrading treatment. The Committee finds that it must be assumed that it would always amount to inhuman treatment to return someone to a situation of armed conflict where the person will be in real danger of being targeted at random or individually by acts of war. The Committee does not consider it necessary to draft a particular provision aimed at this type of situation. ${ }^{73}$

The Government Bill stated further that 'the Ministry agrees with the Committee that persons covered by article 15(c) of the Qualification Directive will be covered by the general protection against return to inhuman treatment .... The Ministry has as a point of departure that it is unfortunate to separate groups that are protected because of a certain reason (war, general violence or disturbances and so forth). It is a key factor of the protection, according to article 3 of the European Convention and subsection (b), that it does not matter what the reason for the protection need is. ${ }^{74}$

According to Christiansen, subsection (b) could be applicable in the case of armed conflict in two distinct scenarios; persons who upon return risk being subjected to random violence, and persons who risk being subjected to war crimes. ${ }^{75}$ The distinction between these two scenarios is that the first could be seen to equate to a generalized risk of violence, which is not covered by the provision. However, the level of intensity separates it from sporadic violence, which should be taken into account when applying the provision. In the second scenario, the persons risk being subjected to war crimes upon return, which, according to Christiansen, is normally a violation to the integrity of the individual, for example, torture or inhuman or degrading treatment. In this latter case, subsection (b) should be considered as applicable. Christiansen highlights however that 15 (c) refers to the first scenario of 'indiscriminate violence'.

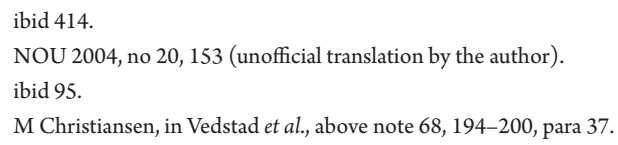


In 2010, the Grand Board of the Norwegian Appeal Board took two precedent-setting decisions assessing the possible application of section 28(b) in regard to return to Mogadishu and South Somalia. ${ }^{76}$ In the first case, the Grand Board found that the Qualification Directive is not part of Norwegian law, but even if 'war refugees' were to be covered by section 28(b) interpreted in the light of article 15(c) of the Directive, it would require an exceptional situation. Moreover, there must be a real risk that the person will be affected individually. The Grand Board did not find the situation in Mogadishu, or Somalia, to be such that it meets the threshold for indiscriminate violence according to the Directive, or that the random acts that may affect the applicant would reach the threshold required by the European Court of Human Rights.

The decision can be compared to the reasoning in a ruling by the first instance court, Oslo Tingrett, which, although not precedent-setting, can overturn decisions by the Administrative Appeal Board. ${ }^{77}$ The Court stated that, on the basis of the travaux préparatoires, protection needs generated because of armed conflict or other situations of violence can fall within the scope of article 3 and the Norwegian provision 28(b) even if it is not explicitly mentioned. With a reference to country of origin information from UNHCR, the Tingrett found that the applicant would be in real danger of inhuman treatment upon return to Mogadishu and that section 28(b) can be applied to situations covered by article 15(c) of the Directive, and that article 3 of the ECHR can be applied to situations of generalized violence when it reaches an extreme level.

The Grand Board of the Norwegian Appeal Board reviewed the situation again in another decision in October 2011. In the second case, the general security situation was considered to constitute a real risk triggering subsection (b). The decision has however been criticized because it does not define whether there is a state of armed conflict in Somalia, nor if war crimes take place that may warrant protection against torture, or inhuman or degrading treatment. ${ }^{78}$

In December 2012, the Grand Board again reviewed the situation in Somalia and concluded that there had been significant changes in the security and humanitarian situation because of al-Shabaab's withdrawal that would enable the Board to reconsider its decision. ${ }^{79}$ The Board looked in particular at the reduction in the number of casualties, improved access by humanitarian agencies, and increased freedom of movement. The majority found, with reference to $A A$ and others $v$ Sweden, that the high levels of crime and lack of effective state protection against the effects of criminalized violence did not constitute 'extreme violence' that would warrant general protection. ${ }^{80}$ It should however be noted that $A A v$ Sweden and others refers to the intensity of conflict, which was not addressed by the Grand Board. ${ }^{81}$ The minority held however that the fact that there was no rule of law, no effective protection from state authorities, and a general unpredictability of the situation, would qualify as a real risk for anyone who is present in Mogadishu.

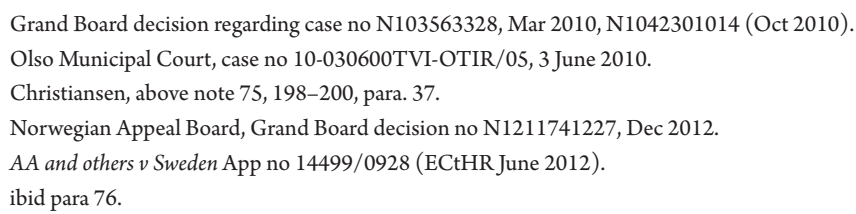




\subsection{Sweden}

\subsection{1 'Persons otherwise in need of protection'}

In 1975, the existing practice of granting de facto status in Sweden was codified in the Swedish Aliens' Act, which divided persons in need of international protection into refugees, conscientious objectors, and de facto refugees. ${ }^{82}$ The definition of a 'de facto refugee' was a person with refugee-like grounds who, without being a refugee, could not return to his or her country of origin due to the political conditions in that country. In practice, it was found that most cases of 'conscientious objectors' and de facto refugees could have fallen under the refugee definition.

Pursuant to the travaux préparatoires, possible categories that could be considered as being 'in a refugee-like situation' were those who applied for asylum but where the standard of proof had not been reached for Convention refugee status. ${ }^{83}$ Another group were persons who had not been exposed to 'persecution' in the past but to a lower level of harassment, such as repeated arrests and detention, with the purpose of barring them from certain professions or educational institutions. ${ }^{84}$ Persons forced to leave their country of origin because of armed conflict were in practice accorded politico-humanitarian status, instead of protection status. ${ }^{85}$ There was therefore a perception that persons fleeing armed conflict were not genuinely in need of protection, a notion that still persists.

Nobel, who studied the practical application of de facto status in the 1980s, identified three categories of persons who were granted such status: first, persons who could qualify for Convention status but who chose not to apply for fear of losing the option of returning to their country of origin for family visits; secondly, so-called 'border-line cases', that is, persons who did not qualify for refugee status because they did not fully meet the criteria, where de facto status was a safety net; and, finally, 'persons who ... fled because of the new refugee situations in Asia, Africa, Central America and pre-1989 Eastern Europe, who are not covered by the 1951 Convention/1967 Protocol, but have nevertheless been "forced out" of their countries'. ${ }^{36}$

At the same time, an exception to granting de facto status was introduced, which still lives on, if not in law at least in the mind of the practitioners, in cases where there may be 'special reasons' to deny protection to those in need. The legislator specified in the travaux préparatoires that in the case of a mass influx, Sweden may not be able to admit large numbers of persons in need of protection and therefore there should be a 'saving clause' allowing the Government to refuse to grant protection. One example of when this 'saving clause' was invoked was in the case of Turkish Assyrian refugees in $1976-82 .{ }^{87}$ In 1989 , the number of asylum applicants rose by 50 per cent after the end of the Cold War and the Government decided to use the 'saving clause' again, the so-called 'December decision', and to only grant protection to Convention refugees. ${ }^{88}$

\footnotetext{
82 Regeringens proposition om ändring i utlänningslagen (1954:193) mm, proposition 1975/76:18, 108-09.

83 A Popovic and G Noll, 'Flyktingstatus - en marginaliserad resurs is svensk asylrätt' (2005-06) 4 Juridisk Tidskrift 834-65.

84 Proposition 1975/76:18, above n 82, 108-9. cf G Melander, 'Ett utvidgat flyktingbegepp' in G Melander (ed), Nordisk flyktingrätt (Studentlitteratur 1985) 50.

85 Svensk migrationspolitik i globalt perspektiv, proposition 1996/97:25.

86 P Nobel, 'What Happened with Sweden's Refugee Policies?' (1990) 2 IJRL 268.

87 ibid 271.

88 E Abiri, 'The Changing Praxis of “Generosity”: Swedish Refugee Policy During the 1990s' (2000) 13 JRS 15.
} 
In 1997, the Swedish Aliens' Act was amended and the concept of 'persons otherwise in need of protection' was introduced in order to harmonize Swedish practice with other European countries and UNHCR's Guidelines. The category 'persons otherwise in need of protection' was interpreted to include persons with a well-founded fear of being sentenced to the death penalty or corporal punishment, or of being subjected to torture or other inhuman or degrading treatment or punishment, and, for the first time, to aliens in need of protection because of external or internal armed conflict or who cannot return to the country of origin because of an environmental disaster. It also included aliens who have a well-founded fear of persecution because of gender or sexual orientation. ${ }^{89}$

The concept of 'persons otherwise in need of protection' was further expanded, in 2004, through legislative changes to include, apart from de facto refugees and 'conscientious objectors', those who were previously granted status on politico-humanitarian grounds, while gender-related persecution was moved into the provision on refugee grounds. In 2010, the Aliens' Act was amended to transpose article 15(b) and (c) of the Qualification Directive verbatim, while the additional protection ground 'persons otherwise in need of international protection' was retained, but moved to another provision..$^{90}$

\subsubsection{Scope of 'persons otherwise in need of protection'}

The Swedish Aliens' Act (2005:716) now divides persons forcibly displaced because of armed conflict into three distinct categories; (i) those leaving because of an armed conflict (chapter 4, section 2, first sentence, subsidiary protection), (ii) because of an external or internal armed conflict (section 2a, first sentence), (iii) because of 'other severe conflicts' in the country of origin (section $2 \mathrm{a}$, second sentence). Both the latter are accorded status as 'persons otherwise in need of protection'.

Two distinctions need to be made, first, between the scope of application of the two forms of internal armed conflict, subsidiary protection and person 'otherwise in need of protection'. According to the travaux préparatoires, the scope of application of the subsidiary protection provision is more restrictive, since it only applies to civilians and requires a serious and individual threat to life or person, while the provision on persons 'otherwise in need of protection' is applicable to everyone, without any requirement of an individualized risk assessment. ${ }^{91}$

The second distinction is between the two provisions on persons 'otherwise in need of protection' because of generalized violence. The main difference between 'internal conflict' and 'severe conflict' lies in the interpretation of the level of intensity. The travaux préparatoires of the Swedish Aliens' Act interpret 'severe conflict' to include situations of political instability in the country of origin where the power structures are such that the legal system does not impartially protect civilians' fundamental human rights. In regard to the parties to the conflict, it may be a conflict between different

\footnotetext{
ibid.

In May 2009, the Commission's case against Sweden for non-communication of measures fully transposing the Qualification Directive resulted in a ruling by the European Court of Justice that Sweden had breached art 226 EC Treaty 559 . The case was closed in Jan 2010 after Sweden had communicated legislative measures, which it claimed fully transposed the Directive. Proposition 2009/10:31, 118.
} 
groups in the population; between a group from the population in one part of the country and the government; or, between the government or a civilian group in the country and another government, where the conflict does not reach the level of an internal armed conflict. ${ }^{92}$

However, in order to invoke the provision of 'other severe conflict', the applicant must show a well-founded fear of serious abuse, and that there is a nexus between the severe conflict and the possible abuse. ${ }^{93}$ The definition of what constitutes 'serious abuse' is interpreted to be broader than how the Qualification Directive defines 'serious threat' in regard to the type of human rights violation (for instance, including harassment) and the level of seriousness of the violation. In a Guiding Decision, the Swedish Migration Board has interpreted the individualization of fear that has to be established as when the applicant is 'personally at risk' with some 'particular circumstance' that demonstrates this. ${ }^{94}$ A UNHCR 2007 study on the implementation of the Qualification Directive in selected EU member states found that the consequence of this interpretation was an expectation that the applicant should be at greater risk than others in a similar situation, which would be contrary to the European Court of Human Rights case-law in, for example, Salah Sheekh $v$ the Netherlands. ${ }^{95}$

The Swedish Aliens' Act has one additional category that may qualify for complementary protection, 'persons otherwise in need of protection' (chapter 4, section 2a, second sentence), that is, persons fleeing an environmental disaster. The travaux préparatoires prescribe that this provision can be applied in the case of a sudden disaster, and when it would be contrary to the spirit of humanity to return someone to the country where such a disaster has taken place. ${ }^{96}$ This provision has not been applied in practice to date. The Commission of Inquiry assessing the transposition of the Qualification Directive into Swedish law proposed that this provision be moved to another chapter of the Aliens' Act as it does not pertain to protection in the sense of the Directive. ${ }^{97}$ The provision was retained however as a category of 'persons otherwise in need of protection'.

\subsubsection{Criteria for risk assessment}

In 2007, the Migration Court of Appeal took a precedent-setting decision on a claim by an applicant from Iraq, which determined the threshold for what should constitute an internal armed conflict according to the current section 2a (first sentence) of the Swedish Aliens' Act. The criteria for an internal armed conflict according to the Court should be that there are clashes between a state's armed forces and other organized groups, that the level of violence rise above the level of sporadic and isolated acts of violence and, finally, the armed group should exercise territorial control enabling them to

92 Proposition 1996/97:25, above n 85, 99; Ny instans- och processordning i utlännings- och medborgarskapsärenden proposition 2004/05:170, 274.

93 Reconfirmed in the position, Swedish Migration Board, Rättsligt ställningstagande angående skydd vid 'andra svåra motsättningar $i$ hemlandet, RC 01/2014, 9 Jan 2014.

$94 \quad$ Guiding Decision on Iraq, Swedish Migration Board, 5 July 2007.

95 UNHCR, 'Asylum in the European Union: A Study of the Implementation of the Qualification Directive' (November 2007) 74; Salah Sheekh v The Netherlands App no 1948/04 (ECtHR, 11 Jan 2007).

96 Proposition 1996/97:25, above n 85, 100-01.

$97 \quad$ SOU 2006:6, 166-69. 
carry out military operations. The Court found that the situation in Iraq did not constitute an internal armed conflict in the sense of the Swedish Aliens' Act, based on a very narrow interpretation of the concept of 'armed conflict. ${ }^{\prime 8}$ Instead, Iraqi applicants would be assessed under the provision on 'severe conflict', which entailed both an assessment of personalized risk and an assessment of the nexus between the expected harm and the severe conflict, which therefore put the threshold for qualification quite high.

The Migration Court of Appeal had in fact adopted a domestic interpretation of what constitutes internal armed conflict, instead of being guided by international humanitarian law. ${ }^{99}$ In 2009, the Migration Court of Appeal reviewed the matter of the threshold for armed conflict in three cases on Somalia and adopted a broader and more inclusive interpretation, inter alia by also taking into account common article 3 of the Geneva Conventions, and by attempting to harmonize its interpretation with international standards and the case law of other European countries. ${ }^{100}$ In these precedentsetting cases, the Court found that the situation in Mogadishu did indeed constitute an internal armed conflict, which meant that the provision is now applicable to a greater number of asylum applications.

The 2011 study of the Migration Courts' practice showed that that the Courts use the definition from the Somalia rulings of 'internal armed conflict' with reference to the impact on civilian population and generalized violence also when assessing 'internal armed conflict' in accordance with the provision on subsidiary protection. ${ }^{101}$ As mentioned previously, according to the Elgafaji judgment, there should be a 'sliding scale' when assessing the need for personal risk when applying subsidiary protection. ${ }^{102}$ However, the Migration Courts assess the personal risk as a rule in all cases of subsidiary protection, regardless of the intensity of violence. It should also be noted that, the evaluation of the intensity of the conflict is linked to the assessment of whether there is armed conflict and not to the assessment of the real risk of harm to civilians. ${ }^{103}$

In regard to risk assessment of 'persons otherwise in need of protection' because of a severe conflict, the travaux préparatoires stipulated that the threshold for 'severe abuse' in a situation of 'severe conflict' should be lower than that of 'persecution' in the refugee definition. The requirements in practice of what constitutes this type of act and the intensity of the act is higher than what is recommended by the travaux préparatoires. However, a project by UNHCR assessing the quality of first instance decision-making, conducted in 2011, also showed that in 39 per cent of the cases where there was a situation of severe conflict, the application was rejected because of a lack of nexus between

98 Ruling by the Migration Court of Appeal, MIG 2007:9, 26 Feb 2007.

99 R Stern, 'Folkrättens roll $i$ vägledande migrationsrättslig praxis' (2010) 4 Svensk Jurist Tidning 358-76; J Magnusson, 'A Question of Definition - The Concept of Internal Armed Conflict in the Swedish Aliens' Act' (2008) 10 EJML 381-409. There has been discussion in recent years about whether international humanitarian law should be the guiding light for migration authorities when assessing whether a situation qualifies as armed conflict. cf, H Storey, 'Armed Conflict in Asylum Law: The 'War-Flaw' (2012) 31 RSQ1-32; J-F Durieux, ‘Of War, Flows, Laws and Flaws: A Reply to Hugo Storey' (2012) 31 RSQ 161-76.

100 Ruling by the Migration Court of Appeal, MIG 2009:27, 6 Oct 2009.

101 A Segenstedt and R Stern, Vad krävs för att få skydd? (Swedish Red Cross Stockholm 2011), 34-35.

102 Elgafaji, above n 53, 39.

103 UNHCR, Safe at Last?, above n 51, 32. It is at this stage not clear how the judgment by the CJEU in Diakité v Commissaire général aux réfugiés et apatrides, case C-285/12, (2014) WLR (D) 37, will affect the interpretation of internal armed conflict and thereby the distinction between the two articles. 
the severe abuse and the severe conflict. ${ }^{104}$ This was notwithstanding the fact that in 96 per cent of the cases the applicant claimed past abuse, which could qualify, according to the definition in the Aliens' Act, as 'severe abuse'. Moreover, UNHCR found it problematic that there is no individual determination of the cases, which the Aliens' Act prescribes, but a comparison is made to what happens to others and a check that it is part of the general security situation in that part of the country. The result is that the application of persons 'otherwise in need of protection' in practice becomes quite restrictive.

\subsubsection{Caveats}

The fact that there are currently three different provisions in the Swedish Aliens' Act whose scope of application and demarcations are somewhat overlapping creates gaps in the factual application, instead of filling them. ${ }^{105}$ According to the travaux préparatoires of the Swedish Aliens' Act, the purpose of the introduction of the ground on 'severe conflict' was to ensure that these claims were dealt with as claims for protection rather than on humanitarian grounds, as had previously been the practice. It was particularly emphasized that this provision should be applied in cases of human rights abuses against women and to encompass severely traumatized individuals who otherwise may not fulfil the requirement for well-founded fear. ${ }^{106}$ Furthermore, the travaux préparatoires explicitly state that the purpose of the introduction of these two concepts was not to restrict the possibility for applicants to receive residency permits. However, the criteria that are stipulated for protection on the basis of severe conflict set the threshold high, in that there is a need to show individualized persecution, as well as a nexus between the human rights violations and the conflict.

In regard to the other provision on persons 'otherwise in need of protection' because of internal and external armed conflict, at the time of the Mogadishu rulings, this was the only provision in Swedish law on internal armed conflict and, even though it was broader than 15 (c), it was also considered to be applicable to cases falling under this provision. As pointed out by Stern, the ruling was basically a mixture of common article 3 and Additional Protocol II to the 1949 Geneva Conventions and article 2 and 15(c) of the Qualification Directive. ${ }^{107}$ In 2010, the Qualification Directive was however formally transposed, adding the 'official' ground of internal armed conflict. A 2011 study comparing the application of the two concepts of internal armed conflict in the practice of the second instance Migration Courts found in fact that the broader provision on armed conflict was not utilized in practice during the four-month period that the project lasted. ${ }^{108}$ It can therefore be questioned whether it is necessary to have an the additional ground on international armed conflict after the Elgafaji judgment confirmed that there is no requirement of individualized risk for subsidiary protection. ${ }^{109}$

L Feijen and E Frennmark, Kvalitet i svensk asylprövning. En studie av Migrationsverkets utredning av och beslut om internationellt skydd (UNHCR Stockholm 2011) 173-80. 
The situation in Syria showed however another dimension of the applicability of the different articles constituting parts of a comprehensive toolkit adaptable to the nuances of an evolving situation. At the end of 2011, the Swedish Migration Board categorized the situation as 'other severe conflict', in January 2012, directives for inhibition of return were issued that were also applicable to those who did not fulfil the individual criteria for protection, in June 2012, the situation was reclassified as 'internal armed conflict', which enabled the applicants to receive a three-year residence permit, while in September 2012, it was reconfirmed that it was an internal armed conflict, but that permanent residence permits should be issued as there was no end of the conflict in sight. ${ }^{110}$

\section{CONCLUSION}

What conclusions can be drawn when comparing the use of complementary forms of protection in the Nordic countries? The first must be that, although the intention stated in the travaux préparatoires for the status was to expand the scope of beneficiaries of international protection, the fact is that complementary protection is often used where refugee or subsidiary protection could have been used. The second conclusion is that the threshold for its application is higher, or its application is for a more limited group of beneficiaries, than was originally intended. It can therefore be questioned whether these complementary forms of protection adhere to the criteria of the Treaty establishing the European Community of being more favourable and ensuring the coherence of Community action.

Are there then any benefits of retaining complementary forms of protection outside the scope of EU harmonization? On paper, of course, it sounds good to have additional protection grounds. It is a fact that the EU acquis only provides the minimum in terms of protection. Prior to the harmonization of subsidiary protection, there were a number of other categories that benefitted from different forms of complementary protection where states felt obliged to provide protection from refoulement, most notably persons fleeing generalized violence because of human rights abuses, and persons displaced because of environmental or humanitarian disasters. These categories remain outside the scope of EU harmonization. Moreover, the Common European Asylum System is still a system in statu nascendi, where the interpretation of the directives is in progress, but is far from complete. Until the European Court of Justice interprets all aspects of the article 15 , there is likely to remain divergences between the member states in how they choose to interpret it, which complementary protection ad interim ensures is covered.

However, there are also inherent traps in having protection statuses that fall outside those that European countries feel themselves legally bound by. Despite very clear travaux préparatoires and guidance from the legislator that the intention with complementary forms of protection is to capture those who fall between other statuses and to grant status to everyone who deserves it, in practice it is quite restrictively used. The reason for this may be that complementary forms of protection do not seem to be designed to identify persons in need of protection, but are rather an act of generosity towards those who 'almost' qualified. In several of the Nordic countries, the origin of complementary protection was to grant status to those who could not show sufficient 
evidence or had lacked credibility and therefore did not receive refugee status. This may still be a factor, which taints the perception of those who are assessed for complementary forms of protection.

Furthermore, even though the Nordic countries have a 'single procedure' assessing all protection (and humanitarian) claims, which should take into account all available evidence, the assessment on complementary protection is often seen as an assessment of 'returnability' and not of 'eligibility', that is, the emphasis of the assessment is on whether there are obstacles to return rather than if the criteria are fulfilled to obtain a status. There is also an element of discretion and a lack of clarity in how and when these statuses are used, without clear case law and guidelines on their application, a fact which can be called into question from the perspective of rule of law.

Finally, in some of the countries, there was the possibility in the past of suspending de facto status when numbers exceeded the reception and absorption capacity of the country. Although this is no longer the case according to the legislation, there is still an underlying misconception that complementary protection can be suspended when the numbers of applicants are too high. This idea is contrary to international refugee law, which clearly provides that persons in need of protection should be identified and be granted such status as they may qualify for, regardless of the numbers of applicants.

In sum, complementary protection can be a useful mechanism to ensure protection for groups with protection needs outside the existing international and regional conventions that are applicable. However, it is essential that the 1951 Convention, and articles 3 of the CAT and the ECHR are used to their full potential first, to ensure protection to persons who qualify for protection under these instruments, and through the application of the subsidiary protection in the Qualification Directive. 